\title{
PALATALIZATION IN BRAZILIAN \\ PORTUGUESE AND ITS EFFECTS ON THE \\ PHONOLOGICAL LEARNING OF ENGLISH AS A \\ FOREIGN LANGUAGE
}

A PALATALIZAÇÃO DO PORTUGUÊS BRASILEIRO E SEUS

EFEITOS NA APRENDIZAGEM DA FONOLOGIA DO INGLÊS

LÍNGUA ESTRANGEIRA

Clerton Barboza ${ }^{1}$

\begin{abstract}
This paper investigates the effects of Brazilian Portuguese (BP) alveolar stop palatalization $\left./ t, d / \rightarrow[t\}, d_{3}\right]$ on the phonological learning of English as a Foreign Language (EFL). It aims to answer the following research question: What is the role of BP palatalization on EFL phonological learning? Grounded on a usage-based view of language (BYBEE, 2010), it is hypothesized that EFL learners follow different phonological learning patterns depending on their specific BP dialect. The data analysis confirms this hypothesis, as palatalizing BP informants tend to produce higher levels of palatalization in the target language.
\end{abstract}

Keywords: usage-based phonology; exemplar model; palatalization.

Resumo: $O$ estudo objetiva investigar efeitos da palatalização das oclusivas alveolares $/ t, d / \rightarrow[t], d 3]$ do Português Brasileiro $(P B)$ na aprendizagem da fonologia do Inglês Língua Estrangeira (ILE). Tem, por pergunta problema, "Qual o papel da palatalização do PB no aprendizado da fonologia do ILE?” Numa visão de língua baseada no uso (BYBEE, 2010), hipotetiza-se que aprendizes de ILE seguem diferentes padrões de aprendizagem a depender do seu falar do PB. $A$ análise dos dados confirma a hipótese, uma vez que aprendizes palatalizadores no PB tendem a maiores níveis de palatalização no ILE.

Palavras-chave: fonologia de uso; modelo de exemplares; palatalização.

\section{Introduction}

The main objective of this study is to investigate the effects of Brazilian Portuguese (BP) alveolar stop palatalization /t, d/ $\rightarrow\left[\mathrm{t} \int, \mathrm{d} 3\right]$ on the phonological learning of English as a Foreign Language (EFL). Palatalization is a phenomenon associated with low proficiency and, accordingly, its realization may cause problems in intelligibility.

1 Professor da UERN, pesquisador do CNPq. 
The study aims to answer the following research question: what is the role of BP palatalization on EFL phonology learning? The study hypothesizes that EFL learners follow different phonology learning patterns depending on their specific BP dialect. The fact that BP palatalization is spreading to non-palatalizing dialects through gradient, word-specific, implementation (CRISTÓFARO-SILVA et al., 2012) anticipates the emergence of noncategorical palatalization for both BP and EFL data.

Grounded on usage-based phonology (BYBEE, 2001), on the exemplar model (PIERREHUMBERT, 2001), and on a view of language as a complex adaptive system (BECKNER et al., 2009), this article advocates that the phonetic and phonological levels are actually indistinct, thus recognizing the relevance of phonetic detail, which is often neglected in formal models (CHOMSKY; HALLE, 1968).

Following this introduction section, the article presents a literature overview that discusses the production of alveolar stops by both BP and EFL informants. It then presents the methodology section. The following section presents the results and discussion arguments. Finally, the article presents its concluding remarks. 8569

\section{BP literature overview}

Most BP dialects produce alveolar stops / $t$, $d$ / followed by the [i] vowel as palatalized variants [t $\int$, d3] (CAMARA, 1995). The phenomenon is associated to specific regional dialects (NASCENTES, 1953; CASTRO; PISCIOTTA, 2002; LEITE; CALLOU, 2002), being traditionally described as categorical (CAGLIARI, 2002).

BP sociolinguistic research diverges on which the effects of such variables as gender, tonic syllables and phonotactic patterns are (HORA, 1990; BISOL, 1991; ABAURRE; PAGOTTO, 2002; BATTISTI; GUZZO, 2009). The literature also observes the interaction of palatalization with other phonological phenomena, such as syncope, allowing for the emergence of BP alveolar affricates [ts, ds] (BISOL, HORA, 1993). As the focus of this article is EFL palatalization, an analysis of those BP variables has been carried out in another study (BARBOZA, 2013).

A usage-based, non-categorical, view of BP alveolar stop palatalization phenomenon is proposed nowadays by some researchers, emphasizing the roles of variation, token frequency and phonetic detail on its emergence. Confronting the categorical status of BP palatalization emergence, Albano $(1999,2001)$ defends a gradient view. The author points out gradient palatalization emergence on specific phonotactic patterns by subjects whose dialect is not marked by BP palatalization emergence. 
Cristófaro-Silva (2003a) supports the view of a gradient emergence of palatalization in BP. The author discusses certain properties of the phenomenon, which in most extreme cases may form minimal pairs, i.e. TAM [tã] "Brazilian airliner" $\neq$ tchã [t $\mathrm{t} a \tilde{]}$ " interjection", tal [tav] "a certain person" $\neq$ tchau $\left[\mathrm{t} \int \mathrm{a} \sigma\right]$ "bye", tê [te] "letter $\mathrm{t} " \neq$ tchê [t $\left.\mathrm{e}\right]$ "interjection". These examples indicate future phonologization. Cristófaro-Silva (2003b) presents a palatalization continuum (Fig. 1a), in which [ti] and [ $\mathrm{t} f \mathrm{i}]$ forms start competing (Fig. 1b). Palatalized exemplars gradually become stronger than non-palatalized ones (Fig. 1c), up to the point in which unexpected forms emerge (Fig. 1d).
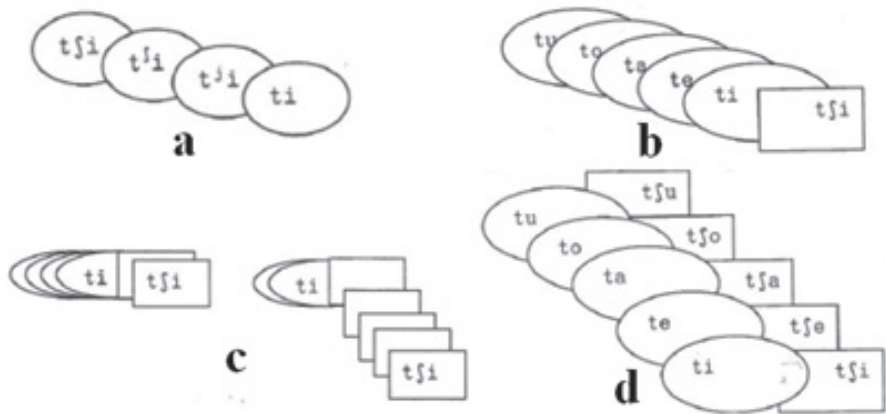

Fig. 1 - Exemplars in competition (CRISTÓFARO-SILVA, 2003b, p. 218-220).

Cristófaro-Silva (2006) rejoins the discussion focusing on the gradient properties of BP palatalization emergence on word borders. The realization of an alveolar stop [t] in certain frequently juxtaposed phonotactic contexts allows the emergence of palatalization on lexical word chunks in BP, i.e. oito e meia "eight thirty" [oj'tui'meja] $\rightarrow$ [oj'twi'meja] $\rightarrow$ [oj'ti'meja] $\rightarrow$ [oj't $\mathrm{fi}$ ' meja]. The analysis is similar to the one presented by Bush (2001), regarding L1 English data, discussed later in this article.

Guimarães $(2004,2008)$ emphasizes the relevance of the individual on the emergence of palatalization in BP. The author draws attention to a high individual rate of variation on homogeneous groups of college students and infants learning BP, emphasizing the role of frequency of use and specific lexical items on the emergence of a more palatalized BP realization.

Finally, results obtained by Barbosa (2011) reinforce the relevance of phonetic detail on the emergence of palatalization in BP. The acoustic analysis carried out by the author reveals changes towards a palatalized realization, mostly imperceptible, by informants on a dialectal contact situation. The gradient change from non-palatalized to palatalized BP realization is perceived by the quantitative analysis of fine phonetic detail 
which serves as an aid to determining [t, d] point of articulation, i.e. centroid, its variance, kurtosis and asymmetry of the fricative noise. A similar analysis has been carried out in a small part of the dataset presented in this article, but gradient data are not presented owing to limitations discussed in the methodology section.

The literature reviewed above indicates the gradient nature of the emergence of palatalization in BP, and shows the relevance of such variables as frequency of use, phonotactic context, the individual, as well as the role of specific lexical items. The incipient literature dealing with the emergence of palatalization by Brazilian EFL learners is discussed next.

\section{EFL literature overview}

In the lexical level, palatalization in L1 English is associated with alveolar obstruents [t, d, s, z] followed by the palatal glide [j] in morphological derivations, i.e. habit/habitual, grade/gradual, confess/confession, please/ pleasure (JONES, 1969).

In the post-lexical level, Bush (2001) reports palatalization to be associated to frequency of juxtaposition. Higher frequency L1 English sequences like would you [wodzo] are more prone to palatalization than lower frequency sequences like good you [godjə]. Brazilian learners are therefore exposed to a palatalization phenomenon, which may be considered similar to the one found in BP, influencing their EFL realization.

Only marginal data are found in the literature focusing on the emergence of EFL palatalization by Brazilian learners. Bettoni-Techio (2005) studies alveolar stop realization in word-final position by Brazilian EFL learners. The author finds a small level of palatalized realizations (14\%), but does not associate EFL palatalization to a regional BP dialect. On the other hand, Arantes (2007) studies the same context by very young Brazilian EFL learners. The author raises the hypothesis that the variable 'BP dialect' might be associated to the emergence of EFL, but this is not conclusive as the aforementioned variable had not been controlled.

Ferreira $(2007 ; 2011)$ deals with the realization of word-final stops in CVC and CVCV lexical items. In the first study, affrication or palatalization is associated to about $40 \%$ of all data regarding alveolar stops. The author concludes, in the second study, that frequency of use has a significant effect on the unexpected EFL palatalization, as more frequent lexical items allow smaller palatalization levels.

Nevins and Braun (2009) have focused on spurious alveolar stop palatalization by Brazilians learning English in the USA. The authors offer a generative view of the phenomenon, based on unsystematic observation. 
They conclude palatalization is closely associated with alveolar stops [ $\mathrm{t}$, d] followed by [u], i.e. two [t $\mathrm{u} \mathrm{u}:]$. The fact has been associated with the phenomenon of goose-fronting, a more front realization of American English [u:]. This would allow the BP palatalization rule to emerge unexpectedly on this case. Nevins and Braun (2009) conclude spurious palatalization may not be associated to aspiration, as it occurs in contexts which are not normally

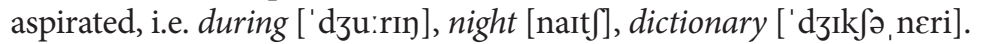

As regards the limited literature involving palatalization by EFL Brazilian learners discussed above, this article has the potential to highlight a linguistic phenomenon that is spreading to most BP dialects and has effects on L2 language learning. The next section presents the methodology of data collection and analysis carried out in this study.

\section{Methodology}

This is a hypothetical-deductive, quasi-experimental, cross-sectional study. It has been approved by the Research Ethics Committee at Universidade Federal do Ceará (process number 242.265). It has involved two informant groups of Brazilian EFL learners, from Fortaleza-CE and Mossoró-RN, as seen in Fig 2.

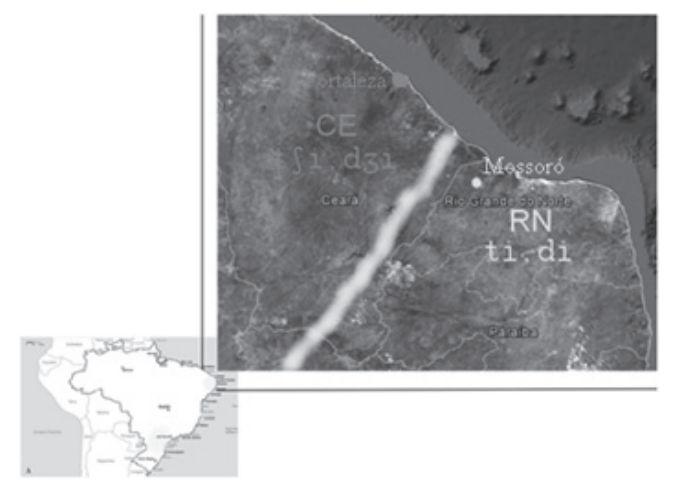

Fig. 2 - Map of Brazil showing areas in which BP dialects tend to non-palatalized realizations (yellow). Map of Ceará-CE and Rio Grande do Norte-RN states, in northeastern Brazil, whose $\mathrm{BP}$ dialects are recurrently palatalized and non-palatalized.

The data from 36 informants have been analyzed in this study, with each dialect contributing with 18 participants, 9 male and 9 female. Variables such as age, socioeconomic status and formal education have not been controlled. Although these are important variables in most sociolinguistic studies, it was 
impossible to find, for example, lower-class, illiterate, 60-year-old subjects attending EFL courses in both regions. Informants who were selected were middle-class young adults of both genders, who either attended or had just concluded an undergraduate degree. Informants were controlled by their EFL proficiency level in beginner, intermediate and advanced groups, according to formal L2 exposure (PRAXEDES, 2007).

Five experiments were used for data collection. Two BP experiments (P1 \& P2) aimed to confirming general dialect trends of either palatalized or non-palatalized realizations, according to each $\mathrm{BP}$ local dialect. They involved a picture induced conversation and the reading of words in carrier-sentences. Three EFL experiments (E1, E2 \& E3) focused on understanding the role of BP palatalization in L2 phonology. They involved repeating low-pass filtered words, reading words in carrier-sentences, and a picture induced memory game. For the sake of brevity, results presented in this article have been amalgamated ${ }^{2}$.

For this study, 39 Portuguese and 73 English words were selected, all of which with phonotactic patterns that might trigger alveolar stop palatalization in both languages. Words were additionally controlled by token frequency. BP phonotactic patterns followed by example words are:

(a) /t, d/ $\rightarrow$ [t $\mathbf{f}, \mathbf{d} \mathbf{3}]$ / _ [i] (i.e. tio "uncle", jardim "garden", etc., 23 words);

(b) $/ \mathbf{t}, \mathbf{d} / \rightarrow[\mathbf{t} \mathbf{f}, \mathbf{d} \mathbf{3}] /$ _ /iu/ (i.e. rádio "radio", indio "indian", etc., 5 words);

(c) $/ \mathbf{s t} / \rightarrow[\mathbf{f t}]] /$ _ /i/ (i.e. plástico "plastic", realístico "realistical", etc., 5 words);

(d) $/ \mathbf{t}, \mathbf{d} / \rightarrow$ [ts, ds] / _ /iS/ (i.e. antes "before", despertador "alarm clock", etc., 6 words).

Different word numbers for each pattern were used owing to previous studies (CRISTÓFARO-SILVA et al., 2012) indicating that the RN/CE dialects allow the emergence of novel BP affricates for phonotactic patterns (b), (c), and (d), which are not so frequent as pattern (a).

English phonotactic patterns followed by example words are:

(a) $/ \mathbf{t}, \mathbf{d} / \ldots$ _ i / (i.e. teacher, $C D$, etc., 15 words);

(b) /t, $\mathbf{d} / \ldots$ / $/$ / (i.e. ticket, dizzy, etc., 25 words);

(c) $/ \mathbf{t}, \mathbf{d} / \ldots / \mathbf{u} /$ (i.e. two, do, etc., 11 words);

(d) __t t, d/ \# (i.e. night, good, etc., 11 words);

(e)__/ts, ds/ \# (i.e. nights, goods, etc., 5 words).

The aforementioned phonotactic patterns do not allow L1 English palatalization. Patterns (a), (b), (c), and (e) were chosen owing to their similarity to BP patterns that are known to influence affricate emergence.

2 See Barboza (2013) for a more comprehensive discussion of the topics covered and summarized in this article. 
Pattern (d) was chosen owing to the constant reports of unexpected EFL palatalization for the realization of alveolar stops in coda position by the literature. Finally, phonotactic pattern (f) _ / $/ \mathbf{t}, \mathbf{d} / \# / \mathbf{j} / \ldots$ (i.e. did you, meet you, etc., 6 words) was chosen for its expected English affricate emergence on the literature. Palatalization by Brazilian EFL learners may or may not emerge on any of the aforementioned phonotactic patterns.

The differences regarding the number of target words in each pattern was associated to the difficulty of developing EFL data collection experiments that could be used for beginner level students. Another limitation was the impossibility of using exactly the same syllable patterns in both languages, as phonotactic patterns obviously differ. The problem could be partially solved by a careful analysis of beginner EFL books, but had a direct impact on word selection.

The variables controlled in this study are:

(a) BP dialect: controlled for the first time in a Brazilian EFL study;

(b) Gender: the literature on BP does not offer a consensus on its role;

(c) EFL proficiency: higher proficiency is expected to reduce BP dialect influence;

(d) Voicing: the literature on BP indicates higher palatalization on voiceless alveolar stops;

(e) Tonic syllable: the literature on BP does not offer a consensus on its role;

(f) Individual: inter-individual differences are important to understanding linguistic patterns (LARSEN-FREEMAN; CAMERON, 2008);

(g) Word: different words, with the same phonotactics, may behave differently (LEITE, 2006);

(h) Word frequency: more frequent words might influence EFL palatalization (BYBEE, 2008); (i) Phonotactic pattern: this variable may play a relevant EFL palatalization role as observed on BP (CRISTÓFARO-SILVA et al., 2012).

The data collection has been carried out with a laptop computer, a Zoom H4n digital recorder and a Shure WH20 headset microphone, following field-work procedures (LADEFOGED, 2003). Even though we acknowledge that a gradient analysis (BARBOSA, 2011) is important for an understanding of the phenomenon, the present study has opted for a categorical discussion of both BP and EFL alveolar stop realizations.

The choice for a categorical rather than a gradient analysis has been made owing to the fact that this is the first study that thoroughly analyses the impact of BP alveolar stop palatalization on EFL realization. It serves thus as a glance at the influences BP dialects have on L2 phonology learning. Besides, the high number of BP/EFL tokens in this study has made the task of analyzing phonetic detail difficult up to the moment. 
A visual/auditorial inspection of all tokens was carried out on Praat (BOERSMA; WEENIK, 2012). Through these procedures, it was possible to categorize most of the tokens in either palatalized on non-palatalized realizations, especially through the observation of the frequencies' centroid and its variance, which is lower and more diffuse for palatalized realizations as compared to their alveolar counterparts (FOREST et al., 1988; JONGMAN et al., 2000). Duration and intensity of the burst associated to alveolar stop release also served as good indicators of palatalization, as palatalized realizations tend to present longer and higher intensity patterns.

A more time-consuming analysis of such fine-grained phonetic detail was carried out in about $15 \%$ of the tokens, which corresponded to those cases in which a categorical classification between either palatalized or non-palatalized alveolar stop realizations was problematic. In this study, we refrain from discussing such results as we have been currently engaged in expanding the gradient analysis of both BP and EFL realization to the whole dataset, to be published in the near future.

Finally, statistics have been performed in SPSS (PEC, 2008). As only categorical data are presented below, this article focuses on Chi-Square $\left(\chi^{2}\right)$ Tests for parametrical and Fisher Exact Tests for non-parametrical data, as well as on independent-sample $t$ tests. The results obtained in the statistical analysis are presented at the bottom of all figures. In the following section, we focus on the data results and discussion.

\section{Results and discussion}

This section presents data on BP and EFL alveolar stop realization by Brazilian learners. Owing to our focus on EFL data, BP data is partially presented below. Fig. 3 presents data involving BP realization of alveolar stops in both $\mathrm{CE}$ and $\mathrm{RN}$ dialects. Token percentage is expressed by the height of the columns on the y axis, whilst token number is presented over the columns.

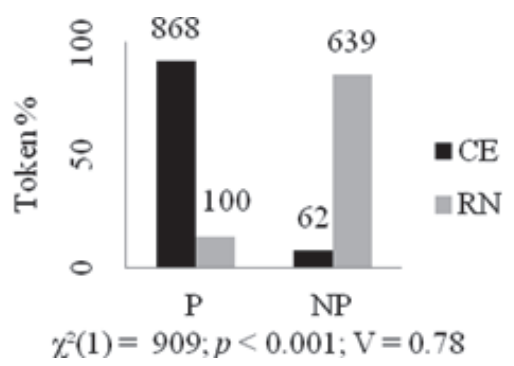

Fig. 3 - BP palatalized (P) vs. non-palatalized (NP) alveolar stop realizations by $\mathrm{CE} / \mathrm{RN}$ informants. 
Even though a significant difference between palatalized alveolar stops in $\mathrm{CE}$ and $\mathrm{RN}$ is found by the chi-square, a non-categorical emergence of the phenomenon on both BP dialects is noticeable. As indicated by the literature, CE informants tend to produce alveolar affricates in pattern (d) $/ \mathbf{t}, \mathbf{d} / \rightarrow[\mathbf{t s}$, ds] / _ /is/ through vowel syncope. On the other hand, RN informants allow similar levels of affricate emergence, but are more prone to palatalization in patterns (b) /tt, d/ $\rightarrow[\mathbf{t} \mathbf{f}, \mathbf{d} 3] / \ldots / \mathbf{i u} /$ and (c) $/ \mathbf{s t} / \rightarrow[\mathbf{f t} \mathbf{f}] / \ldots / \mathbf{i} /$. Results indicate palatalization is beginning to emerge in the $\mathrm{RN}$ dialect though specific pathways (CRISTÓFARO-SILVA et al., 2012). This fact anticipates higher than expected rates of EFL alveolar stop palatalization by $\mathrm{RN}$ informants.

Traditional phonological theory assumes phonetic dialect-specific phenomena such as palatalization as irrelevant for the creation of underlying representations (CHOMSKY; HALLE, 1968). This fact implies limited influence of L1 palatalization on L2 phonology learning. On the other hand, usage-based phonology (BYBEE, 2001) assumes that L1 phonetic detail is crucial for mental representations, thus having a significant impact on L2 realization. Data on Fig. 4 supports the latter theory.

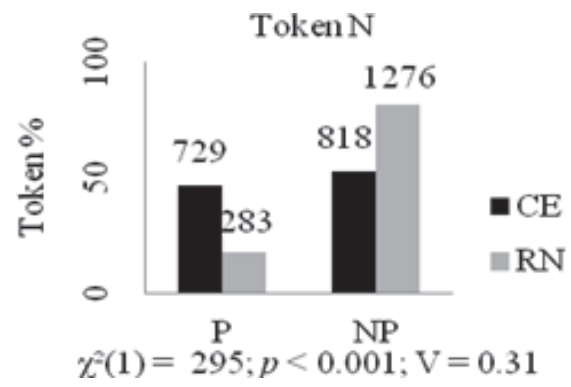

Fig. 4 - EFL palatalized (P) vs. non-palatalized (NP) alveolar stop realizations by CE/RN dialect.

A Chi-square statistical analysis indicates EFL CE informants palatalize significantly more than their RN colleagues. As expected, CE informants do not palatalize in EFL as much as in BP. This is associated with a gradual awareness of the fact that EFL palatalization is not expected in most cases in which BP palatalization would emerge. As regards RN data, results disallow rule-based, categorical, phonological approaches to EFL palatalization, as RN informants allow EFL palatalization to some degree. This is observable owing to the gradual emergence of palatalization on RN data. It may be hypothesized that EFL palatalization by RN informants is 
associated with a smaller contact with L2 input, thus allowing a recurrent emergence of EFL palatalization on a trial and error basis.

The literature on BP palatalization (HORA, 1990; BISOL, 1991; ABAURRE; PAGOTTO, 2002; BATTISTI; GUZZO, 2009) diverges on the role of gender in the phenomenon. Data regarding gender and EFL palatalization by Brazilian learners is presented on Fig. 5 .

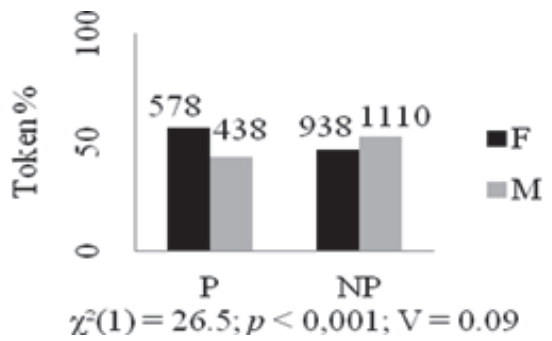

Fig. 5 - EFL palatalized (P) vs. non-palatalized (NP) alveolar stop realizations by female (F) and male (M) informants.

Chi-square results indicate gender played a significant role in the emergence of EFL palatalization, as female informants are more prone to palatalize than their male colleagues. A group-specific analysis reveals a significant difference between RN female and male informants, whereas only non-significant differences involving $\mathrm{CE}$ female and male informants are found for EFL palatalization. As regards BP data, a group-specific BP dataset analysis reveals non-significant differences for both BP dialect groups. These results pose a problem: if $\mathrm{RN}$ females do not show higher alveolar stop palatalization levels than their male colleagues in BP, why do they produce higher rates of palatalization in EFL? It may be hypothesized that the competition of exemplars in BP (CRISTÓFARO-SILVA, 2003a) by female $\mathrm{RN}$ informants may be already pending to palatalized realizations, though this is still non-significant statistically. The hypothesis is based on Sociolinguistic literature assuming that females are more prone to linguistic change towards a prestigious L1 dialect (LABOV, 2008). L2 learning would allow higher EFL palatalization levels by RN female informants, probably owing to the lack of phonological constraints associated with the realization of a novel phonological structure.

It was expected that BP dialect influence would be reduced as higher EFL proficiency levels are achieved. Fig. 6 presents data regarding EFL palatalization and proficiency levels. 


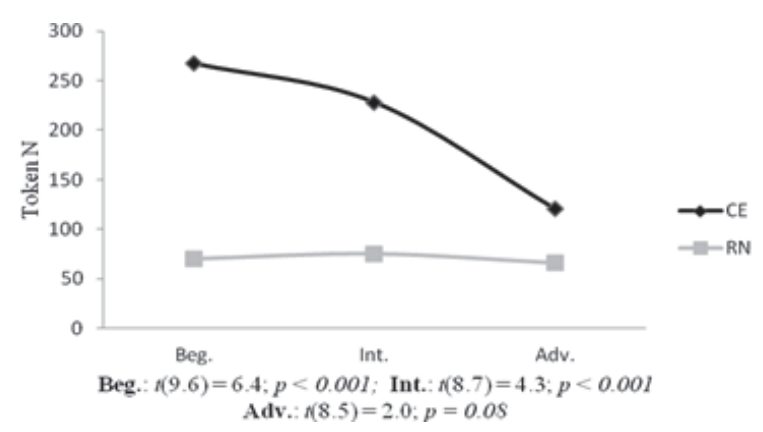

Fig. 6 - CE and RN EFL palatalized realizations in three proficiency levels

Independent-sample $t$ tests indicate that $\mathrm{CE}$ informants show significantly higher EFL palatalization rates than RN informants for beginner and intermediate learners, but not for advanced ones. The data suggest a greater BP dialect influence amongst CE informants in the earlier stages of EFL learning, with a later drop towards a non-palatalized production. This is the expected effect of formal/informal contact with L2 input. On the other hand, the results obtained from the RN informants are associated with a plateau in which EFL alveolar stop palatalization is fossilized through all proficiency levels. These results evince the fact that BP palatalization influences EFL learning trajectories in most proficiency levels, except amongst advanced learners. They also indicate a constant threshold for EFL palatalization by RN students, as the rates of palatalization remain stable through all proficiency levels. This fact may suggest that L1 English affricates act as triggers to unexpected palatalization cases in EFL.

The literature assumes that the voiceless alveolar stop / $/$ is more prone to palatalization in both BP and EFL (ABAURRE; PAGOTTO, 2002; BETTONITECHIO, 2005). Data regarding voicing patterns are presented on Fig. 7.

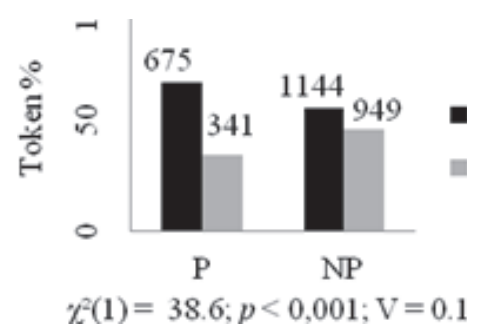

Fig. 7 - EFL palatalized (P) vs. non-palatalized (NP) realizations of voiceless (VL) and voiced (VD) alveolar stops. 
A Chi-square statistical analysis indicates that voiceless stops are significantly more prone to the emergence of EFL palatalization than their voiced counterparts, thus confirming previous findings (ABAURRE; PAGOTTO, 2002; BETTONI-TECHIO, 2005). The causes for this pattern, however, are not clear. Results may be associated either with a higher type frequency of the voiceless alveolar stop /t/ or with a misperception of alveolar stop / $t$ / aspiration, characteristic of the English phonological system. Further studies are necessary to elucidate the question, as this research study did not aim to control these variables.

As regards the tonic syllable, the literature on Brazilian Portuguese predicts the emergence of palatalization in both tonic and pretonic/ postonic positions (ABAURRE; PAGOTTO, 2002; BISOL, 1991). The data involving EFL productions are presented on Fig. 8.

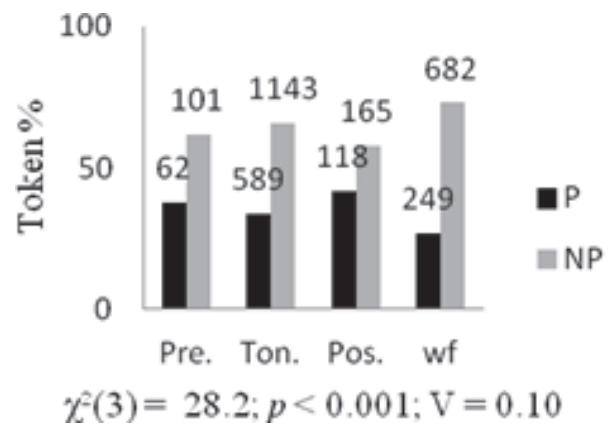

Fig. 8 - EFL palatalized (P) vs. non-palatalized (NP) realizations in pretonic, tonic, postonic, and word final (wf) positions.

The Chi-square test indicates a significant preference for EFL palatalization in the postonic position, followed by pretonic, tonic and word final positions. The EFL and BP results in this study are similar, as the postonic position is more associated with palatalization in both languages. Furthermore, the data regarding EFL palatalization partially cast some doubts on the hypothesis that Brazilian EFL palatalization patterns are associated to aspiration. Higher EFL palatalization rates would be expected on the tonic syllable, in case BP informants misperceived aspiration/palatalization in this context.

Individuals behave according to their L2 proficiency level, with a lower L1 influence at later stages (BARBOZA, 2013). Data involving individual EFL palatalized alveolar stop realizations are presented in Fig. 9. 


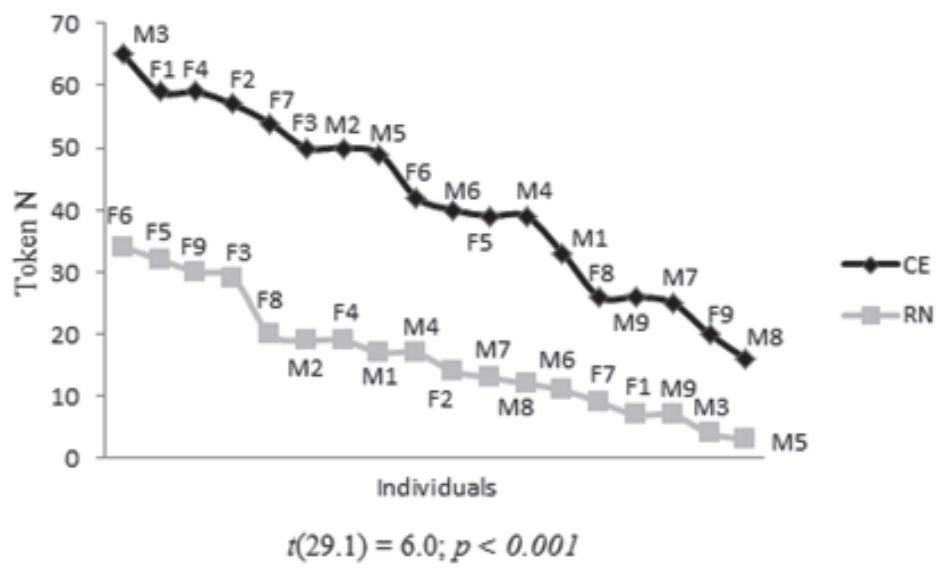

Fig. 9 - EFL palatalized realizations by individual male (M) and female (F) CE and RN informants. Proficiency level is indicated by numbers 1-3 (beg.), 4-6 (int.), and 7-9 (adv.).

The independent-sample $t$ test supports the hypothesis that EFL learners are influenced by their local BP dialect, as differences between groups are significant. Furthermore, it reinforces the need for a more profound study on the role of inter- and intra-individual variation. $\mathrm{RN}$ informants who palatalize the most in EFL are intermediate (F6, F5) to advanced learners (F9), whereas some of the $\mathrm{RN}$ informants who palatalize the least are beginners (F1, M3). CE informants are less susceptible to such levels of individual variation. However, an advanced student (F7) is placed between CE informants who palatalized the most, and a beginner (M1) between those who palatalized the least. Individual analyses, carried out in another study (BARBOZA, 2013), indicate the complex interaction between L1 and L2 phonological patterns (LARSEN-FREEMAN, CAMERON, 2008), as the aforementioned individuals do not behave like standard EFL learners of either palatalized or non-palatalized BP dialects.

Specific lexical items are not usually analyzed in EFL studies with a focus on phonotactic patterns. However, the L1 usage-based literature (BYBEE, 2010) abounds with examples of specific words leading or resisting sound change, thus granting different realization patterns of words with similar phonotactic patterns (LEITE, 2006). Having the results presented so far in mind, it is expected that EFL words realized by $\mathrm{CE}$ informants allow higher palatalization levels than RN informants. Due to space limitations, Fig. 10 focuses on a small selection of the words and short phrases analyzed in this study. 


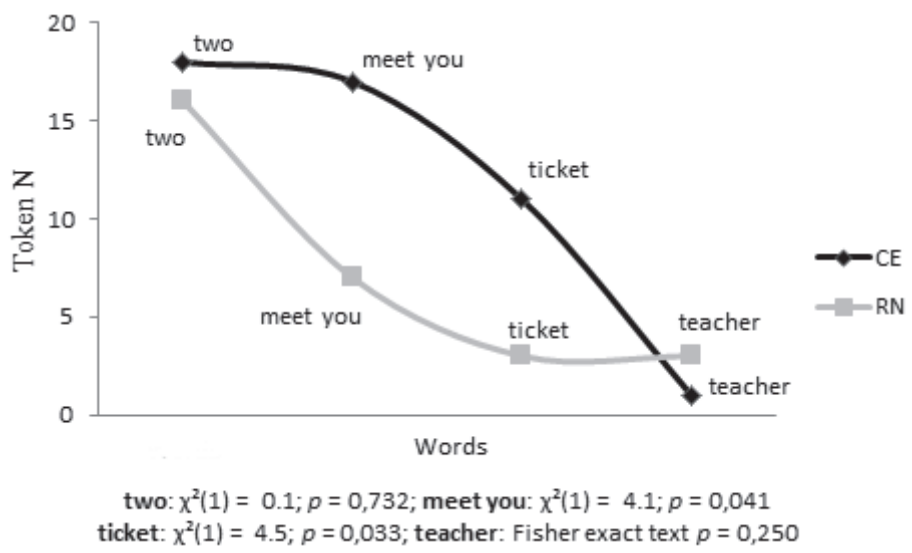

Fig. 10 - EFL words realized with palatalized alveolar stops by CE and RN informants.

The Chi-squares and Fisher exact test whose results are shown above only partially support the hypothesis that the BP dialect has an effect on EFL phonology learning. The words two and teacher are cases in which informants of both $\mathrm{CE}$ and $\mathrm{RN}$ groups share similar EFL realization patterns. The former is characterized by a high number of palatalized tokens in both groups, whereas the latter presents a small number. Words with similar phonotactic patterns, i.e. toon, tea, are produced tending to a palatalized or non-palatalized production by each BP dialect group, thus emphasizing the relevance of the lexical item on L2 phonology learning. It may be hypothesized that high frequency plus explicit teaching time dedicated to the word teacher account for its lower levels of palatalization by CE EFL learners, which is even lower than the rates shown by their RN colleagues. A hypothesis for the high palatalization of the word two is more challenging, as the previous hypothesis does not hold for this word. On the other hand, data concerning the EFL words meet you and ticket indicates they behave according to the dialect influence of BP. CE informants tend to palatalize these words significantly more than their RN colleagues, as it had been predicted, given their local BP varieties. Therefore, results indicate the word is a relevant variable for analyzing L2 data, having the potential of aiding the understanding of BP phonological influence on EFL.

Frequency of use and its effects in L1 sound change have already been investigated (BYBEE, 2010). Its effects on L2 learning are not so well understood, but usage-based phonology expects high-frequency L2 tokens to be realized more accurately than low frequency ones (BYBEE, 2008). 
Fig. 11 reports data involving high- and low-frequency words as regards EFL palatalization rates in both groups.

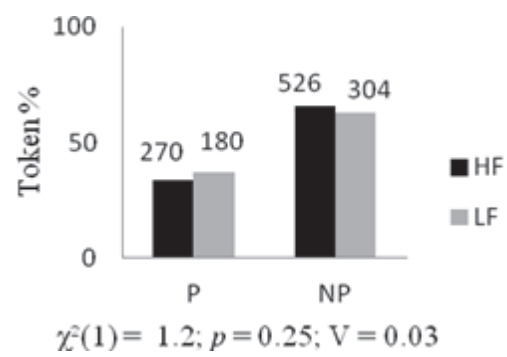

Fig. 11 - EFL palatalized (P) vs. non-palatalized realizations (NP) in high (HF) and low (LF) frequency words.

The Chi-square test reveals only a statistically non-significant effect of frequency of use on EFL palatalization. Furthermore, previous considerations involving the words two and teacher specifically indicate L2 word-frequency may be unforeseeable as the first word allowed high palatalization levels and the second one allowed low levels only. Further studies focusing on word-frequency must be carried out to elucidate the role of this variable in L2 phonology learning.

Finally, specific phonotactic patterns are known to trigger BP alveolar stop palatalization (GUIMARÃES, 2004; CRISTÓFARO-SILVA et al., 2012). As observed previously, this study predicted that CE informants would palatalize EFL alveolar stops more recurrently than their RN counterparts, in all contexts. Fig. 12 presents data from these phonotactic patterns:

(a) $/ \mathbf{t}, \mathbf{d} / \ldots$ _ i / (i.e. teacher, $C D$, etc.) and (c) $/ \mathbf{t}, \mathbf{d} / \ldots / \mathbf{u} /($ i.e. two, do, etc).

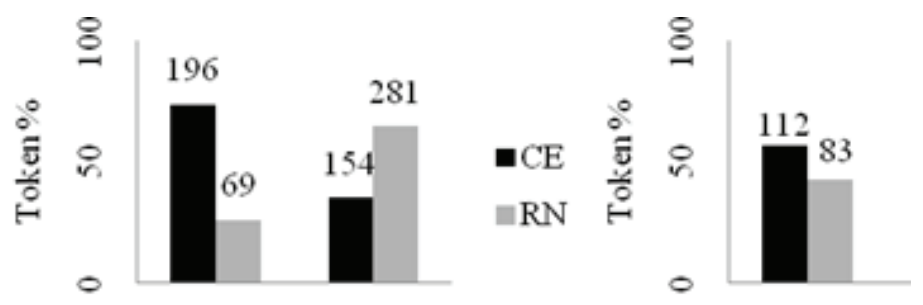

Fig. 12 - EFL palatalized (P) vs. non-palatalized realizations (NP) in phonotactic patterns (a) and (c).

Chi-square tests indicate both phonotactic patterns present statistically significant differences between CE and RN EFL informants, thus reinforcing the role that different $\mathrm{BP}$ dialects have in the production of $\mathrm{L} 2$ features. It is 
evident, however, that there is an effect shown by phonotactic pattern (c) on bringing the EFL alveolar stop palatalization of both groups closer, as compared to pattern (a). It is also important to notice that palatalization in context (c) is unexpected in a BP similar phonotactic pattern. These data might be explained on a usage-based view of the phenomenon, with an L1 exemplar pattern becoming productive in novel L2 patterns. Traditional phonology models would not apply their rules to a novel L2 phonotactic pattern. Results emphasize the need to search for multiple perspectives, as the process of L2 learning may not be easily foreseen.

\section{Conclusion}

This study aimed to investigate the effects of Brazilian Portuguese (BP) alveolar stop palatalization $/ \mathrm{t}, \mathrm{d} / \rightarrow\left[\mathrm{t} \int \mathrm{d} 3\right]$ on the phonological learning of English as a Foreign Language (EFL). It hypothesized that EFL learners follow different phonology learning patterns depending on their specific BP dialect. The data revealed that local BP dialects had a significant influence on Brazilian learners' EFL realization. The results therefore confirmed the main hypothesis. The emergence of EFL palatalized tokens by RN informants were associated to the gradient emergence of $\mathrm{BP}$ palatalization in the $\mathrm{RN}$ dialect, as data indicated similar palatalization levels for both BP and EFL words by $\mathrm{RN}$ informants in specific situations. The analysis also suggested that the process of palatalization by $\mathrm{BP}$ learners was not associated with aspiration in the target language, as it emerged in phonotactic contexts in which high VOT levels are not recurrent in L1 English.

The variables considered significant were: gender, with females tending to palatalize more than males; voicing, with voiceless alveolar stops / $t$ / tending to palatalize more than voiced ones /d/; tonic position, with the postonic syllables tending to palatalize more than tonic and pretonic ones; the individual, with certain informants achieving either high or low unexpected EFL palatalization levels; and the word, with specific lexical items being realized with either high (i.e. two) or low (i.e. teacher) palatalization levels by the informants of both BP dialects. Partially significant results were achieved by the 'L2 proficiency' variable, as the palatalization levels shown by the advanced informants were the only that did not differ significantly from their cross-dialectal colleagues. Amongst informants of both BP dialects, certain phonotactic patterns led EFL palatalization levels to be more similar or dissimilar, even though they failed to achieve statistical significance. Finally, token frequency obtained only non-significant results. 
The literature on L2 phonology has always emphasized the need for language specific instruction according to the learners' L1, disregarding their L1 dialect. The results in this study indicate that dialectal differences in the L1 must also deserve attention, as it plays a significant role in the learning of an L2 phonological system.

\section{REFERENCES}

ABAURRE, Maria B. M.; PAGOTTO, Emílio G. Palatalização das oclusivas dentais no português do Brasil. In: ABAURRE, Maria B. M.; RODRIGUES, Angela C. S. Gramática do português falado: novos estudos descritivos. v. 8. Campinas: Editora da Unicamp, 2002. p. 577-603. ALBANO, Eleonora Cavalcante. O português brasileiro e as controvérsias da fonética atual: pelo aperfeiçoamento da fonologia articulatória. Delta, v. 15, p. 23-50, 1999.

. O gesto e suas bordas: esboço de fonologia acústico-articulatória do português brasileiro. São Paulo: Mercado de Letras, 2001.

ARANTES, Violeta Toledo Piza. Perception and production of English final stops by young Brazilian EFL students. $138 \mathrm{f}$. Dissertação (Mestrado em Letras) - UFSC, Florianópolis, 2007.

BARBOSA, Denise Pozzani de Freitas. Gradientes alofônicos de oclusivas alveolares do português brasileiro em uma situação de contato dialetal. 112 f. Dissertação (Mestrado em Linguística) - UNICAMP, Campinas-SP, 2011. BARBOZA, Clerton L. F. Efeitos da palatalização das oclusivas alveolares do português brasileiro no percurso de construção da fonologia do inglês língua estrangeira. 263f. Tese (Doutorado em Linguística) - UFC, Fortaleza, 2013.

BATTISTI, Elisa; GUZZO, Natália Brambatti. Palatalização das oclusivas alveolares: o caso de Chapecó (SC). In: BISOL, Leda; COLLISCHON, Gisela. Português do sul do Brasil: variação fonológica. Porto Alegre: Edipucrs, 2009. p. 114-140.

BECKNER, C. et al. Language is a complex adaptive system: position paper. Language Learning, v. 51, n. 1, p.1-26, dec. 2009.

BETTONI-TECHIO, Melissa. Production of final alveolar stops in Brazilian Portuguese/English interphonology. 152 f. Dissertação (Mestrado em Letras) - UFSC, Florianópolis, 2005.

BISOL, Leda. Palatalization and its variable restriction. International Journal of the Sociology of Language, n. 89, p.107-124, 1991. 
BISOL, Leda; HORA, Dermeval da. Palatalização da oclusiva dental e fonologia lexical. Revista Letras, Santa Maria, n. 5, p. 25-40, jun. 1993. BOERSMA, Paul, WEENIK, David. Praat: doing phonetics by computer. Version 5.1.43. Disponível em: http://www.praat.org . 2012. BUSH, Nathan. Frequency effects and word-boundary palatalization in English. In: BYBEE, Joan; HOPPER, Paul (Comp.). Frequency and the emergence of linguistic structure. Amsterdam: John Benjamins, 2001. p. 255-280. BYBEE, Joan. Phonology and language use. Cambridge: CUP, 2001. . Language, usage and cognition. Cambridge: CUP, 2010. . Usage-based grammar and second language acquisition. In: ROBINSON, Peter; ELLIS, Nick C. Handbook of cognitive linguistics and second language acquisition. New York: Routledge, 2008. p. 216-236. CAMARA Jr., Joaquim Mattoso. Estrutura da língua portuguesa. 23. Ed. Petrópolis: Vozes, 1995.

CASTRO, Vandersi Sant’ana; PISCIOTTA, Harumi. Palatização no português do Brasil: dados de atlas linguísticos regionais. Estudos Linguísticos, v. 31, p. 1-4, 2002.

CHOMSKY, Noam; HALLE, Morris. The sound pattern of English. New York: Harper \& Row, 1968.

CRISTÓFARO-SILVA, Thaís. A palatalização de oclusivas alveolares no japonês e no português brasileiro. In: MENDES, Amália; FREITAS, Tiago. Actas do XVIII Encontro Nacional da Associação Portuguesa de Linguística. Lisboa: Associação Portuguesa de Linguística, 2003a. p. 293-302. Descartando fonemas: a representação mental na fonologia de uso. In: HORA, Dermeval da; COLLISCHON, Gisela. Teoria linguística: fonologia e outros temas. João Pessoa: Editora Universitária/UFPB, 2003b. p. 200-231.

Modelos multirrepresentacionais em fonologia. In: MARCHEZAN, Renata Coelho; CORTINA, Arnaldo. Os fatos da linguagem, esse conjunto heteróclito. Araraquara: FCL-UNESP Laboratório Editorial, 2006. p. 171-185.

CRISTÓFARO-SILVA, Thaïs et al. Revisitando a palatalização no português brasileiro. Revista de Estudos da Linguagem, Belo Horizonte, v. 20, n. 2, p. 59-89, dez. 2012.

FERREIRA, Ana Paula Petriu. Pet or petty? Diferenças entre palavras CVC e CVCV do inglês por aprendizes brasileiros: uma análise acústica. $131 \mathrm{f}$. Dissertação (Mestrado em Letras) - UFPR, Curitiba, 2007.

. Aquisição de codas em inglês como L2: uma análise à luz da Fonologia de Uso. In: CONGRESSO INTERNACIONAL DA ABRALIN, 7. Anais do VII Congresso Internacional da ABRALIN. Curitiba: Abralin, 2011. p. 267 - 275. 
FORREST, Karen et al. Statistical analysis of word-initial voiceless obstruents: preliminary data. Journal of the Acoustical Society of America, v. 84, n. 1, p. 115-123, 1988.

GUIMARÃES, Daniela Maria Lima Oliveira. Sequências de (sibilante+africada alveolopalatal) no português falado em Belo Horizonte). 122 f. Dissertação (Mestrado em Linguística) - UFMG, Belo Horizonte, 2004.

. Percurso de construção da fonologia pela criança: uma abordagem dinâmica. 333 f. Tese (Doutorado em Linguística) - UFMG, Belo Horizonte, 2008.

HORA, Dermeval da. A palatalização das oclusivas dentais: variação e representação não-linear. 278 f. Tese (Doutorado em Letras) - PUC-RS, Porto Alegre, 1990.

JONES, Daniel. The pronunciation of English. 4th ed. Cambridge: Cambridge University Press, 1969.

LABOV, William. Padrões sociolinguísticos. São Paulo: Parábola Editorial, 2008.

JONGMAN, Allard et al. Acoustics characteristics of English fricatives. Journal of the Acoustical Society of America, v. 108, n. 3, p. 1252-1263, 2000.

LADEFOGED, Peter. Phonetic data analysis: an introduction to fieldwork and instrumental techniques. Malden: Blackwell, 2003.

LARSEN-FREEMAN, Diane; CAMERON, Lynne. Complex systems and applied linguistics. Oxford: Oxford University Press, 2008.

LEITE, Camila Tavares. Seqüencias de (oclusiva alveolar + sibilante alveolar) como um padrão inovador no português de Belo Horizonte. 125 f. Dissertação (Mestrado em Linguística) - UFMG, Belo Horizonte, 2006.

LEITE, Yonne; CALLOU, Dinah. Como falam os brasileiros. 2. ed. Rio de Janeiro: Jorge Zahar Editor, 2002.

NASCENTES, Antenor. O linguajar carioca. 2. Ed. Rio de Janeiro: Organização Simões, 1953.

NEVINS, Andrew; BRAUN, David. The role of underlying representations in L2 Brazilian English. In: CALABRESE, A.; WETZELS, L. Loan phonology. Amsterdam: John Benjamins, 2009. p. 181-191.

PEC. SPSS statistics. Version 17.0. [S.1.]: Polar engineering and consulting, 2008.

PIERREHUMBERT, Janet. Probabilistic phonology: discrimination and robustness. In: BOD, R.; HAY, J.; HOPPER, P. Probability theory in linguistics. Cambridge, MA: The MIT Press, 2002. p. 175-228. 
PRAXEDES, Pedro Henrique Lima. A corpora-based study of the development of EFL Brazilian learners' interlanguage from simplification to complexification in the light of systemic-functional grammar. 1307f. Tese (Doutorado em Letras) - UFSC, Florianópolis, 2007.

Recebido em: 30/11/2014. Aceito em: 27/03/2015. 